\title{
Impression Cytology Screening for Ocular Surface changes in various forms of Vernal Keratoconjunctivitis in Subtropical Central Zone in India
}

\author{
Shreya Thatte ${ }^{1(D)}$, Amit Varma ${ }^{1}$, Seemee Kapadia ${ }^{1}$, Suchi Paliwal ${ }^{1}$, Aviral Vasudeo ${ }^{1}$ \\ ${ }^{1}$ Sri Aurobindo Medical College and Postgraduate Institute, Indore, Madhya Pradesh, India
}

\begin{abstract}
Introduction: Vernal keratoconjunctivitis (VKC) is a chronic recurrent allergic disorder of the eye more common in warm and dry climates like central India. Chronic and recurrent nature of disease requires long duration of treatment which leads to changes in ocular surface leading to cytomorphological distortion of goblet cells, that can be evaluated by impression cytology. Clinical presentation and impact of disease on cytomorphology of ocular surface was analysed in various forms of the VKC. The objective of this study was to find correlation of clinical profile and cytomorphological changes in ocular surface in patients with various forms of vernal keratoconjunctivitis.
\end{abstract}

Materials and methods: This cross sectional study analysed 120 eyes of 60 patients of various forms of vernal keratoconjunctivitis. Detailed history was taken along with complete ophthalmic examination. Vernal keratoconjunctivitis was graded as per Gokhale et al classification. Impression cytology for goblet cell morphology and metaplasia according to classification given by Saini et al was done. Cytological changes were noted for different age groups, duration of disease, and severity of disease.

Results: Vernal keratoconjunctivitis was seen more commonly in males and in the second decade of life which shows a changing trend towards higher age. Milder forms were more commonly present than moderate and severe forms. Mostly Grade 2 changes were seen on impression cytology.

Conclusion: Increasing severity, duration of disease and age of presentation was directly proportionate to greater cytological changes on ocular surface.

Key words: Allergic conjunctivitis, Cytomorphology, Impression cytology, VKC.

\begin{tabular}{|c|c|}
\hline Financial Interest $\quad$ : Nil & Received : 10.11.2020 \\
\hline Conflict of Interest : Nil & Accepted : 20.05.2021 \\
\hline \multicolumn{2}{|l|}{ Corresponding Author } \\
\hline \multicolumn{2}{|l|}{ Dr. Shreya Thatte } \\
\hline \multirow{2}{*}{\multicolumn{2}{|c|}{$\begin{array}{l}\text { Sri Aurobindo Medical College and Postgraduate Institute, } \\
\text { Indore, Madhya Pradesh, India. }\end{array}$}} \\
\hline & \\
\hline \multicolumn{2}{|l|}{ E-mail: shreyathatte@gmail.com } \\
\hline Contact: +919302104864 & \\
\hline
\end{tabular}

Access this article online

Website: www.nepjol.info/index.php/NEPJOPH

DOI: https://doi.org/10.3126/nepjoph.v13i2.32838 Copyright $\odot 2021$ Nepal Ophthalmic Society ISSN: 2072-6805, E-ISSN: 2091-0320

This work is licensed under a Creative Commons Attribution-NonCommercial-NoDerivatives 4.0 International License (CC BY-NC-ND). 


\section{INTRODUCTION}

Vernal keratoconjunctivitis (VKC) is a chronic, recurrent bilateral inflammation of conjunctiva caused by both IgE and cell-mediated immune mechanisms (Bowling, 2016). It is a part of a group of diseases which are classified as allergic conjunctivitis including perennial and seasonal rhinoconjunctivitis, atopic keratoconjunctivitis and giant papillary conjunctivitis.

This disease is more common in warm dry climate and often occurs on a seasonal basis, with a peak incidence occurring in late spring and summer. Approximately $23 \%$ of patients have perennial form of $\mathrm{VKC}$ and more than $60 \%$ of patients suffer from recurrences during the winter (Bonini et al, 2004). 95\% of cases remit by the late teens although many of the remainder develop atopic keratoconjunctivitis.

It primarily affects boys with onset 5 years onwards (mean age of 7 years) (Bowling, 2016). Most common symptoms of VKC are itching, photophobia, burning, mucoid discharge and tearing. The clinical signs commonly seen are giant papillae (cobblestone appearance), superficial keratitis and conjunctival hyperaemia, papillary hypertrophy of the palpebral and/or the limbal conjunctiva, bulbar conjunctival pigmentation, limbal thickening and Horner Tranta's dots.

In developing countries, it can be a potentially blinding disease. Visual loss occurs due to corneal complications such as corneal scars, astigmatism, keratoconus and complications associated with the unsupervised use of topically administered corticosteroids (Bonini et al, 2004). Patients with VKC experience significant morbidity which hampers their quality of life (Sacchetti et al, 2007).

There may be changes in ocular surface which constitute distortion in morphology of goblet cells by chronic and recurring course of disease (Saboo et al, 2013). This ocular surface change can be evaluated by a simple non-invasive technique known as Impression Cytology (Hagan et al, 2017)

This research was undertaken to study VKC in a tertiary eye care centre in Central India to analyse impact of disease on cytomorphology of ocular surface by Impression Cytology.

\section{MATERIALS AND METHODS}

The study was approved by the Institutional ethics and research committee and was conducted in strict adherence to the Declaration of Helsinki law. This is a cross sectional study in which 120 eyes of 60 patients with VKC were examined during the study period from July 2018 to June 2019 in our Tertiary Eye Care Institute. Informed written consent for participation in study was taken by the patient's/ parents or guardians.

The diagnosis of VKC was made on the basis of history, clinical signs and symptoms.

Inclusion criteria for our study constitutes:

1. All diagnosed cases of VKC irrespective of age and gender.

2. Patients without any associated ocular comorbidity.

3. Patients who are willing to participate in the study.

4. Patients without any systemic diseases 
Exclusion criteria for patients included:

1. Patients not willing to participate in the study.

2. Patients having any pre-existing ocular pathology other than VKC.

3. Patients having a history of contact lens use.

4. Patients having history of usage of topical drugs for any ocular pathology other than VKC.

5. Patients having history of any Intraocular surgery.

The demographic data were recorded which include: age, gender, personal and family history (First degree relative) history of allergies, age of onset of the disease, presenting symptoms, duration of disease and drug history. Detailed ocular examination was carried out including visual acuity, refraction; slit lamp examination for clinical signs, intraocular pressure and fundus examination.

After examination patients were labelled as: (Saboo et al, 2013)

1) Palpebral form (cobblestone papillae of $>1$ $\mathrm{mm}$ on the upper tarsal conjunctiva with no limbal infiltration) (Figure 1).

2) Limbal form (papillae of $<1 \mathrm{~mm}$ on the upper tarsal conjunctiva with limbal infiltration) (Figure 2).

3) Mixed form (features of both palpebral and limbal forms) (Figure 3).

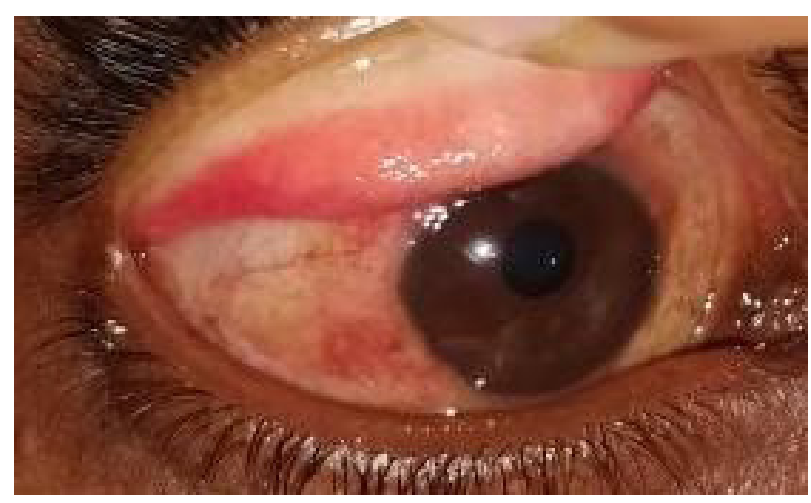

Figure 1: Palpebral form of VKC.

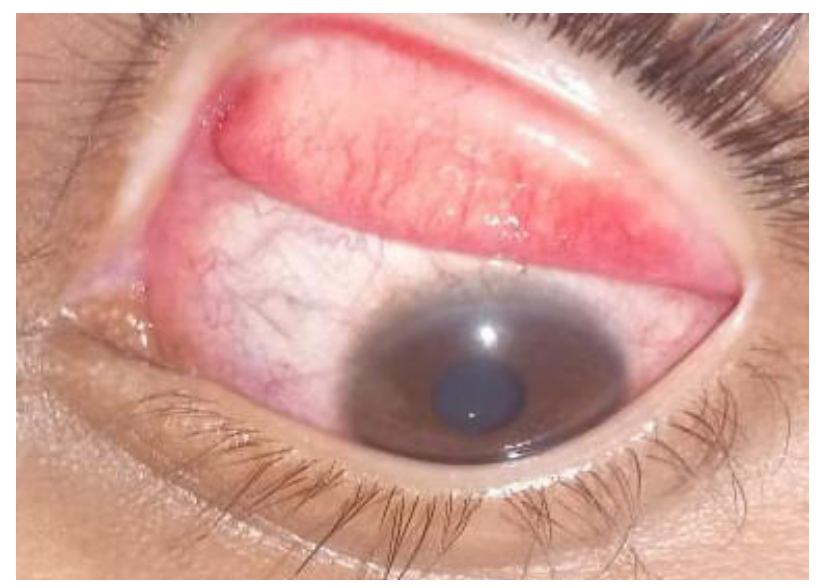

Figure 2: Limbal form of VKC.

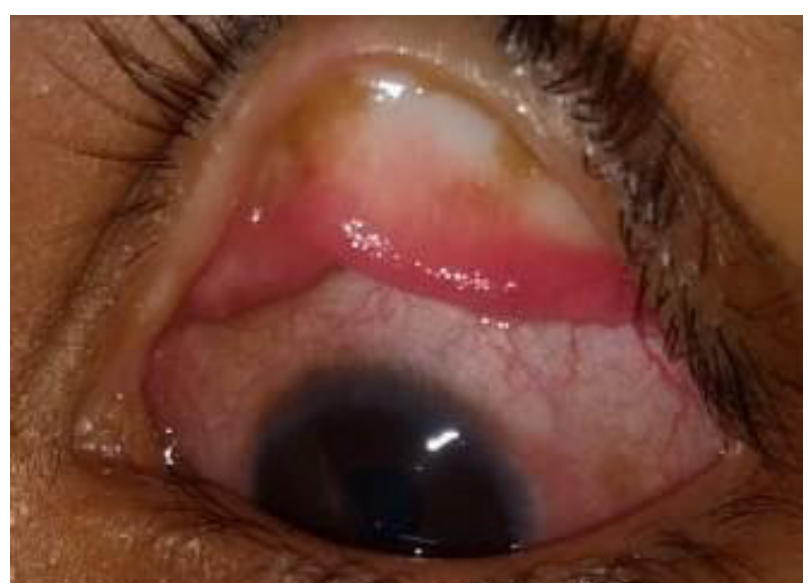

Figure 3: Mixed form of VKC. 


\begin{tabular}{|c|c|c|c|c|c|}
\hline Clinical Finding & Mild & $\begin{array}{c}\text { Moderate } \\
\text { intermittent* }\end{array}$ & $\begin{array}{l}\text { Moderate } \\
\text { Chronic* }\end{array}$ & Severe & Blinding \\
\hline Symptoms & $\checkmark$ & $\checkmark$ & $\checkmark$ & $\checkmark$ & $\checkmark$ \\
\hline Papillae & $\checkmark$ & $\checkmark$ & $\checkmark$ & $\checkmark$ & $\checkmark$ \\
\hline Horner-Trantas dots & $x$ & $\checkmark$ & $\checkmark$ & $\checkmark$ & $\checkmark$ \\
\hline Fine SPEE & $x$ & $\checkmark$ & $\checkmark$ & $\checkmark$ & $\checkmark$ \\
\hline Focal Limbal inflammation (<6 clock hours) & $x$ & $\checkmark$ & $\checkmark$ & $\checkmark$ & $\checkmark$ \\
\hline Cobblestones & $x$ & $x$ & $\checkmark$ & $\checkmark$ & $\checkmark$ \\
\hline Annular limbal inflammation ( $>6$ clock hours) & $x$ & $x$ & $x$ & $\checkmark$ & $\checkmark$ \\
\hline Coarse SPEE/PEK & $x$ & $x$ & $x$ & $\checkmark$ & $\checkmark$ \\
\hline Conjunctival granulomas & $x$ & $x$ & $x$ & $\checkmark$ & $\checkmark$ \\
\hline Limbal deficiency-pannus & $x$ & $x$ & $x$ & $\checkmark$ & $\checkmark$ \\
\hline Macroerosions & $x$ & $x$ & $x$ & $\checkmark$ & $\checkmark$ \\
\hline Shield ulcer & $x$ & $x$ & $x$ & $x$ & $\checkmark$ \\
\hline $\begin{array}{l}\text { LSCD with conjunctivalization vascular } \\
\text { corneal/tarsal scarring }\end{array}$ & $x$ & $x$ & $x$ & $x$ & $\checkmark$ \\
\hline
\end{tabular}

${ }^{\star}$ Intermittent periodicity: $<4$ episodes per year with complete remission,

${ }^{\star}$ Chronic periodicity: All round the year. Remission period $<1$ month. SPEE: Superficial punctate epithelial erosions, SPK: Superficial punctate Keratitis, LSCD: Limbal stem cell deficiency

Figure 4: Severity criteria for VKC.

\section{Courtesy: (Gokhale et al, 2016)}

The severity of the disease was graded based on the clinical signs at initial presentation, as described by Gokhle et al (2016) as it was best suited for our clinical practice (Figure 4).
Impression Cytology specimen were collected from all the four quadrants i.e. superior, inferior, nasal and temporal for all the patients in both eyes by Tseng's modified method (Singh et al, 2005) (Figure 5).
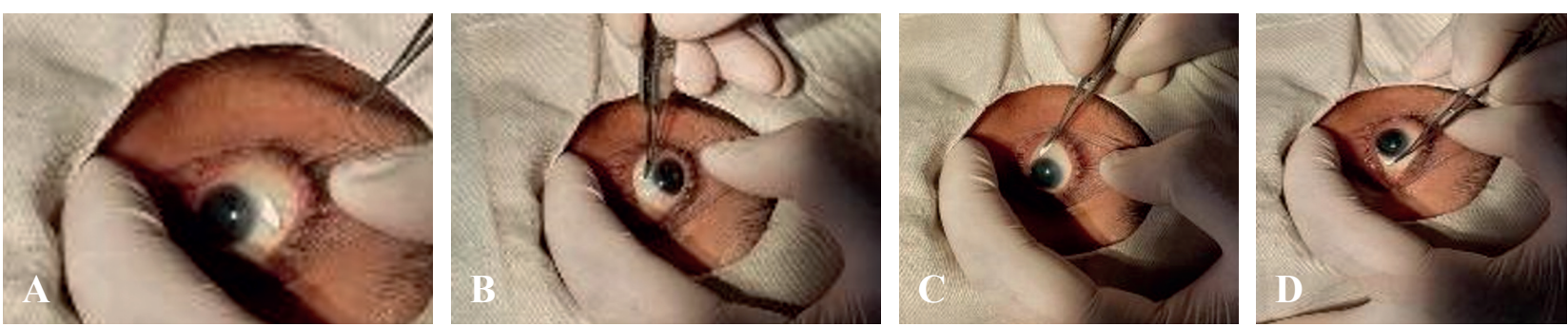

Figure 5: Process of Impression Cytology. 
In Tseng's modified method of specimen collection we use a cellulose acetate filter paper from Millipore and it is trimmed into a $5 \mathrm{~mm}$ strip with one square end and one tapering end. This asymmetrical shape with a pointed tip helps in grabbing and transferring the paper to the desired area with blunt smooth edged forceps.

We used a Millipore paper with a $13 \mathrm{~mm}$ diameter and a pore size of 0.22 micron divided in two ' $D$ ' shaped halves. For orientation the end of the paper applied to the nasal side is clipped. One drop of local anaesthetic is instilled into the eye and excessive tear fluid and medication are wiped away. The paper is placed on the conjunctiva $2 \mathrm{~mm}$ away from the limbus and is allowed to remain in contact with the eye for nearly 5-10 seconds and then peeled off with a forceps. A combination of Papanicolaou and PAS stains were used for staining of Impression Cytology specimens.

Grading for Goblet Cell Morphology and metaplasia was recorded as per following grading given by Saini et al (Ukponmwan, 2003)

- Grade 1: A good confluent sheet of small round epithelial cells having nucleus to cytoplasm ratio of 1:2. Deeply positive goblet cells are present in large numbers (Figure 6).

- Grade 2: A good cell layer showing larger polygonal epithelial cells with a decreased nucleocytoplasmic ratio of 1:3. The number of goblet cells are reduced, but still deeply PAS positive (Figure 7).

- Grade 3: Polygonal cells became larger and nucleus to cytoplasm ratio decreased further. Goblet cells were more reduced with weak staining (Figure 8).

- Grade 4: Large polygonal basophilic cells with pyknosis of the nucleus. Intracellular keratin can also be seen frequently. Goblet cells are absent and only a few clumps were obtainable.

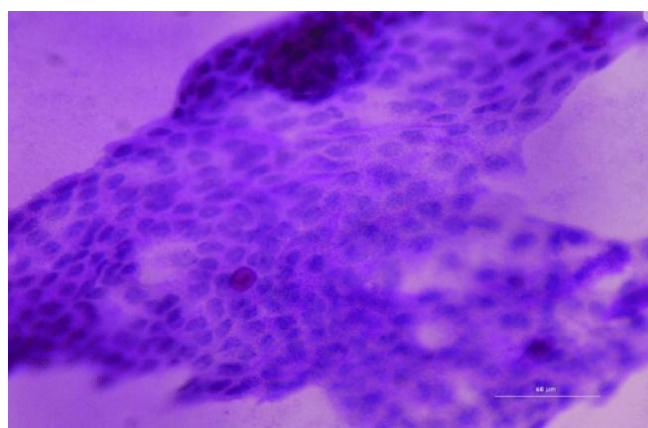

Figure 6: Grade 1 Impression Cytology.

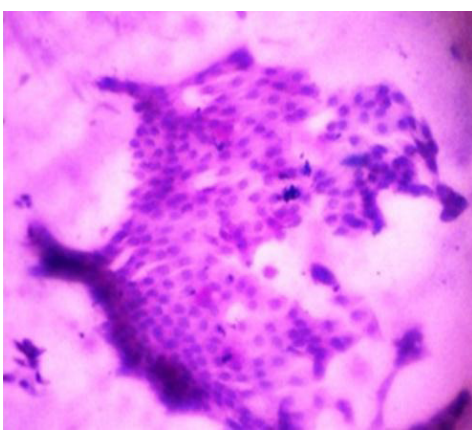

Figure 7: Grade 2 Impression Cytology.

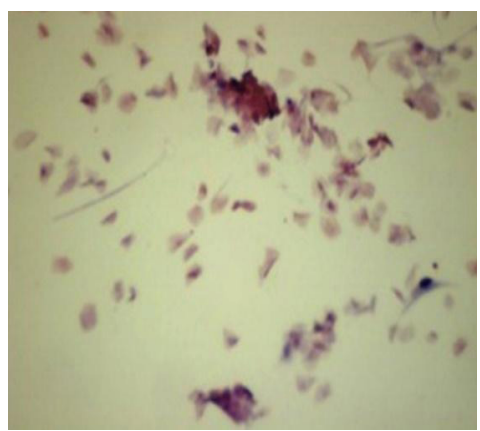

Figure 8: Grade 3 Impression Cytology. 


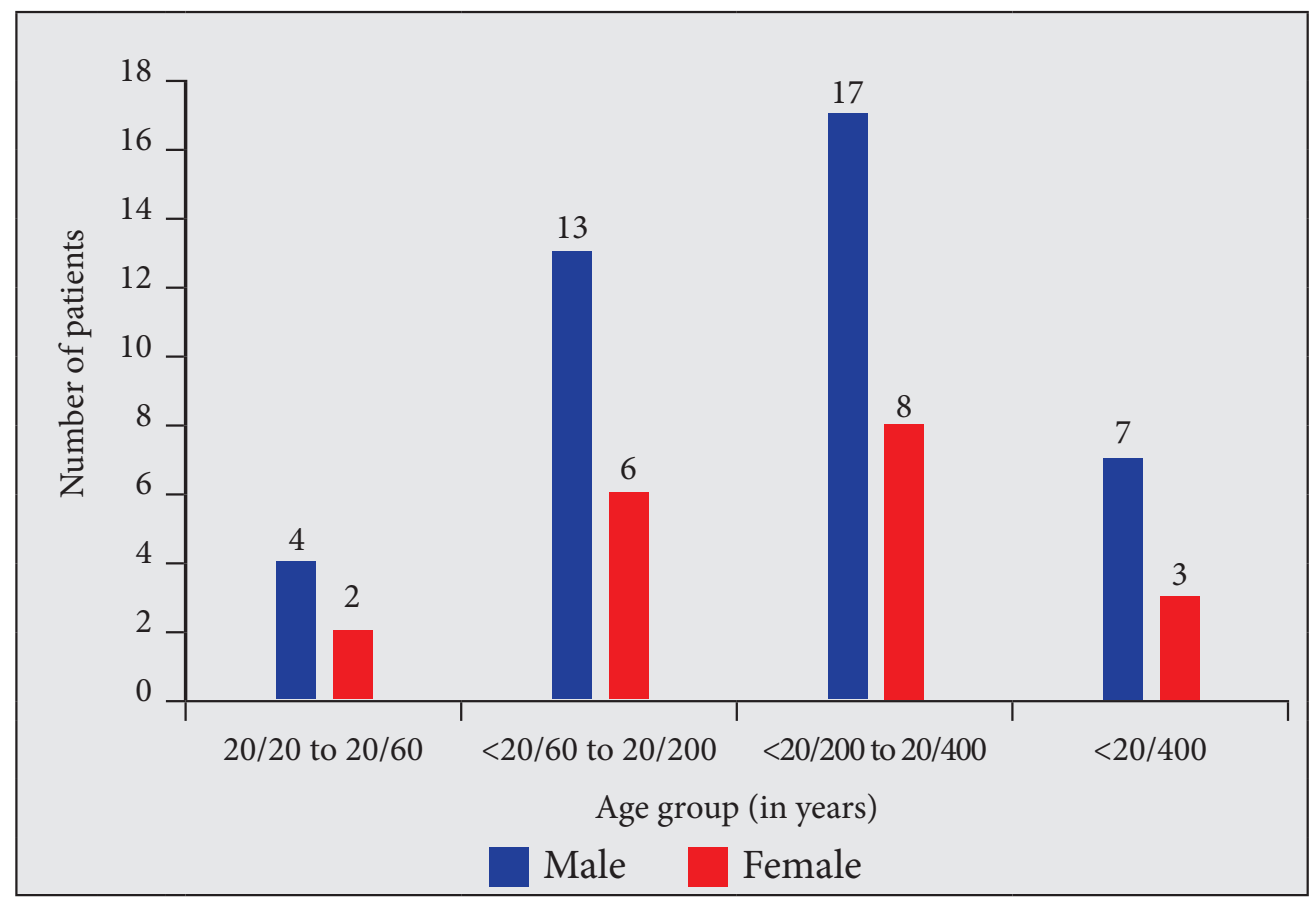

Figure 9: Age and gender based distribution.

\section{RESULTS}

Of 60 patients $41(68.3 \%)$ were males and females were $19(31.7 \%)$; with a male to female ratio of 2.1:1. Most of the cases (41.6\%) were found in the age group of 11-15 years with age range (3-23 years) (Figure 9). 18 of our patients had a short history of less than a month, 21 had history between 1 and 6 months, 7 patients had complaints from a period between 6 to 12 months. Longer duration of disease between 1 to 5 years was found in 9 patients, further 5 patients had a history of more than 5 years.

Of the 120 eyes in our series $46.66 \%$ were mild in intensity, 36.66\% were moderate intermittent, $15.83 \%$ were severe cases and $0.83 \%$ were blinding. None of our cases fell into the category of moderate chronic. Clinically mixed form was found in 55\% cases followed by palpebral forms (40\%) and limbal form (5\%).

All palpebral forms were mild in intensity. In limbal forms two-third cases were moderate intermittent and one third of them were severe. In the mixed variety, 40 out of $66(60.66 \%)$ were moderate intermittent forms followed by severe forms $(25.75 \%)$ (Table 1$)$. 
Table 1: Association of severity and clinical forms of disease.

\begin{tabular}{|c|c|c|c|c|c|}
\hline \multirow{2}{*}{\multicolumn{2}{|c|}{ Severity of VKC }} & \multicolumn{3}{|c|}{ Clinical Forms } & \multirow{3}{*}{$\begin{array}{c}\text { Total } \\
56\end{array}$} \\
\hline & & \multirow{2}{*}{$\begin{array}{c}\text { Palpebral } \\
48\end{array}$} & \multirow{2}{*}{$\begin{array}{c}\text { Limbal } \\
0\end{array}$} & \multirow{2}{*}{$\begin{array}{c}\text { Mixed } \\
8\end{array}$} & \\
\hline Mild & Count & & & & \\
\hline lvila & $\%$ & $100.0 \%$ & $0.0 \%$ & $12.1 \%$ & $46.7 \%$ \\
\hline \multirow{2}{*}{ Moderate } & Count & 0 & 4 & 40 & 44 \\
\hline & $\%$ & $0.0 \%$ & $66.7 \%$ & $60.6 \%$ & $36.7 \%$ \\
\hline \multirow{2}{*}{ Severe } & Count & 0 & 2 & 17 & 19 \\
\hline & $\%$ & $0.0 \%$ & $33.3 \%$ & $25.8 \%$ & $15.8 \%$ \\
\hline \multirow{2}{*}{ Blinding } & Count & 0 & 0 & 1 & 1 \\
\hline & $\%$ & $0.0 \%$ & $0.0 \%$ & $1.5 \%$ & $83 \%$ \\
\hline \multirow{2}{*}{ Total } & Count & 48 & 6 & 66 & 120 \\
\hline & $\%$ & $100.0 \%$ & $100.0 \%$ & $100.0 \%$ & $100.0 \%$ \\
\hline
\end{tabular}

Chi Square Test $=91.008, \mathrm{df}=6 \mathrm{P}$ Value $=0.000$ Significant

The above table shows the association between Clinical Forms and Severity of VKC of the respondents which found to be significant $(\mathrm{P}$ $<0.05)$. It implies that Clinical Forms of patients differ significantly with the Grading of VKC they had.

Patients having Palpebral Clinical Form show the $100 \%$ for Mild Grading of VKC. Patients having Limbal Clinical Form show the highest percentage $66.7 \%$ for Moderate while, none had Mild or Blinding Clinical Forms. Patients having Mixed Clinical Form show the highest percentage $60.6 \%$ for Moderate, while the lowest percentage $1.5 \%$ had Blinding Clinical Forms.

Table 2: Association of Impression Cytology in various severity of disease.

\begin{tabular}{|c|c|c|c|c|c|c|}
\hline \multirow{2}{*}{ Severity of VKC } & \multicolumn{4}{c|}{ Impression Cytology } & \multirow{2}{*}{ Total } \\
\cline { 2 - 7 } & Grade 1 & Grade 2 & Grade 3 & Grade 4 & \\
\hline \multirow{2}{*}{ Mild } & Count & 28 & 24 & 4 & 0 & 56 \\
\cline { 2 - 7 } & $\%$ & $80.0 \%$ & $44.4 \%$ & $13.8 \%$ & $0.0 \%$ & $46.7 \%$ \\
\hline \multirow{2}{*}{ Moderate } & Count & 3 & 25 & 16 & 0 & 44 \\
\cline { 2 - 7 } & $\%$ & $8.6 \%$ & $46.3 \%$ & $55.2 \%$ & $0.0 \%$ & $36.7 \%$ \\
\hline \multirow{2}{*}{ Severe } & Count & 4 & 5 & 8 & 2 & 19 \\
\cline { 2 - 7 } & $\%$ & $11.4 \%$ & $9.3 \%$ & $27.6 \%$ & $100.0 \%$ & $15.8 \%$ \\
\hline \multirow{2}{*}{ Blinding } & Count & 0 & 0 & 1 & 0 & 1 \\
\cline { 2 - 7 } & $\%$ & $0.0 \%$ & $0.0 \%$ & $3.4 \%$ & $0.0 \%$ & $0.8 \%$ \\
\hline \multirow{2}{*}{ Total } & Count & 35 & 54 & 29 & 2 & 120 \\
\hline & $\%$ & $100.0 \%$ & $100.0 \%$ & $100.0 \%$ & $100.0 \%$ & $100.0 \%$ \\
\hline
\end{tabular}

Chi Square Test $=44.901, \mathrm{df}=9 \mathrm{P}$ Value $=0.000$ Significant 
Table 3: Association of Impression Cytology and age group.

\begin{tabular}{|c|c|c|c|c|c|c|}
\hline \multirow{2}{*}{ Age group } & \multicolumn{5}{c|}{ Impression Cytology } & \multirow{2}{*}{ Total } \\
\cline { 3 - 7 } & Grade 1 & Grade 2 & Grade 3 & Grade 4 & \\
\hline \multirow{2}{*}{$1-5$ years } & Count & 8 & 4 & 0 & 0 & 12 \\
\cline { 2 - 7 } & $\%$ & $22.9 \%$ & $7.4 \%$ & $0.0 \%$ & $0.0 \%$ & $10.0 \%$ \\
\hline \multirow{2}{*}{$6-10$ years } & Count & 10 & 21 & 7 & 0 & 38 \\
\cline { 2 - 7 } & $\%$ & $28.6 \%$ & $38.9 \%$ & $24.1 \%$ & $0.0 \%$ & $31.7 \%$ \\
\hline \multirow{2}{*}{$11-15$ years } & Count & 14 & 22 & 14 & 0 & 50 \\
\cline { 2 - 7 } & $\%$ & $40.0 \%$ & $40.7 \%$ & $48.3 \%$ & $0.0 \%$ & $41.7 \%$ \\
\hline \multirow{2}{*}{15 years } & Count & 3 & 7 & 8 & 2 & 20 \\
\cline { 2 - 7 } & $\%$ & $8.6 \%$ & $13.0 \%$ & $27.6 \%$ & $100.0 \%$ & $16.7 \%$ \\
\hline \multirow{2}{*}{ Total } & Count & 35 & 54 & 29 & 2 & 120 \\
\cline { 2 - 7 } & $\%$ & $100.0 \%$ & $100.0 \%$ & $100.0 \%$ & $100.0 \%$ & $100.0 \%$ \\
\hline
\end{tabular}

Chi Square Test $=24.797, \mathrm{df}=9 \mathrm{P}$ Value $=0.003$ Significant

The above table (Table 2) shows the association between Impression Cytology and Grading of $\mathrm{VKC}$ of the respondents which found to be significant $(\mathrm{P}<0.05)$. It implies that Impression Cytology Grades of patients differ significantly with the Grading of VKC they had.

Patients having Grade 1 Impression Cytology show the highest percentage $80 \%$ for Mild Grade while none had Blinding Grading of VKC. Patients having Grade 2 Impression Cytology show the highest percentage $46.3 \%$ for Moderate Grade while none had Blinding Grading of VKC. Patients having Grade 3 Impression Cytology show the highest percentage $55.2 \%$ for Moderate Grade while, the lowest percentage $3.4 \%$ had Blinding Grading of VKC.

Patients having Grade 4 Impression Cytology show $100 \%$ for Severe Grading of VKC.

The above table (Table 3) shows the association between Impression Cytology and age of the respondents which found to be significant ( $\mathrm{P}$ $<0.05)$. It implies that Impression Cytology Grades of patients differ significantly with the age they belong to.

Patients having Grade 1 Impression Cytology show the highest percentage $40 \%$ for $11-15$ years of age while, the lowest percentage $8.6 \%$ belongs to $>15$ years of age. Patients having Grade 2 Impression Cytology show the highest percentage $40.7 \%$ for $11-15$ years of age while, the lowest percentage $7.4 \%$ belongs to $1-5$ years of age. Patients having Grade 3 Impression Cytology show the highest percentage $48.3 \%$ for 11-15 years of age while none belong to 1-5 years of age. Patients having Grade 4 Impression 
Table 4: Association of Impression Cytology and Duration of disease at presentation.

\begin{tabular}{|c|c|c|c|c|c|c|}
\hline \multicolumn{2}{|c|}{$\begin{array}{c}\text { Duration of Disease } \\
\text { at Presentation }\end{array}$} & \multicolumn{4}{c|}{ Impression Cytology } & \multirow{2}{*}{ Total } \\
\cline { 2 - 7 }$<1 \mathrm{MTH}$ & Count & 20 & 10 & 6 & 0 & 36 \\
\cline { 2 - 7 } & $\%$ & $57.1 \%$ & $18.5 \%$ & $20.7 \%$ & $0.0 \%$ & $30.0 \%$ \\
\hline \multirow{2}{*}{$1-6 \mathrm{MTH}$} & Count & 9 & 26 & 7 & 0 & 42 \\
\cline { 2 - 7 } & $\%$ & $25.7 \%$ & $48.1 \%$ & $24.1 \%$ & $0.0 \%$ & $35.0 \%$ \\
\hline \multirow{2}{*}{$6-12 \mathrm{MTH}$} & Count & 4 & 7 & 3 & 0 & 14 \\
\cline { 2 - 7 } & $\%$ & $11.4 \%$ & $13.0 \%$ & $10.3 \%$ & $0.0 \%$ & $11.7 \%$ \\
\hline \multirow{2}{*}{$1-5$ years } & Count & 2 & 10 & 6 & 0 & 18 \\
\cline { 2 - 7 } & $\%$ & $5.7 \%$ & $18.5 \%$ & $20.7 \%$ & $0.0 \%$ & $15.0 \%$ \\
\hline \multirow{2}{*}{$>5$ years } & Count & 0 & 1 & 7 & 2 & 10 \\
\cline { 2 - 7 } & $\%$ & $0.0 \%$ & $1.9 \%$ & $24.1 \%$ & $100.0 \%$ & $8.3 \%$ \\
\hline \multirow{2}{*}{ Total } & Count & 35 & 54 & 29 & 2 & 120 \\
\cline { 2 - 7 } & $\%$ & $100.0 \%$ & $100.0 \%$ & $100.0 \%$ & $100.0 \%$ & $100.0 \%$ \\
\hline
\end{tabular}

Chi Square Test $=55.851, \mathrm{df}=12 \mathrm{P}$ Value $=0.000$ Significant

Cytology show $100 \%$ for $>15$ years of age.

The above table illustrates the association between Impression Cytology and duration of disease at presentation of the respondents which found to be significant $(\mathrm{P}<0.05)$. It implies that Impression Cytology grades of patients differ significantly with the duration of disease at presentation they had.

Patients having Grade 1 Impression Cytology show the highest percentage $57.1 \%$ for $<1$ month duration while none had $>5$ years duration of disease at presentation. Patients

Table 5: Association of Impression Cytology and clinical forms of disease.

\begin{tabular}{|c|c|c|c|c|c|c|}
\hline \multirow{2}{*}{ Clinical Forms } & \multicolumn{4}{c|}{ Impression Cytology } & \multirow{2}{*}{ Total } \\
\cline { 3 - 7 } \multicolumn{2}{|c|}{ Palpebral } & Grade 1 & Grade 2 & Grade 3 & Grade 4 & \\
\hline \multirow{2}{*}{ Limbal } & Count & 30 & 20 & 8 & 0 & 58 \\
\cline { 2 - 7 } & $\%$ & $68.2 \%$ & $35.7 \%$ & $40.0 \%$ & $0.0 \%$ & $48.3 \%$ \\
\hline \multirow{2}{*}{ Mixed } & Count & 12 & 26 & 10 & 0 & 48 \\
\cline { 2 - 7 } & $\%$ & $27.3 \%$ & $46.4 \%$ & $50.0 \%$ & $0.0 \%$ & $40.0 \%$ \\
\hline \multirow{2}{*}{ Total } & Count & 2 & 10 & 2 & 0 & 14 \\
\hline & $\%$ & $4.5 \%$ & $17.9 \%$ & $10.0 \%$ & $0.0 \%$ & $11.7 \%$ \\
\hline & Count & 44 & 56 & 20 & 0 & 120 \\
\hline & $\%$ & $100.0 \%$ & $100.0 \%$ & $100.0 \%$ & $0.0 \%$ & $100.0 \%$ \\
\hline
\end{tabular}

Chi Square Test $=12.379, \mathrm{df}=4$ P Value $=0.015$ Significant 
Table 6: Relation between Age and Duration of disease at presentation.

\begin{tabular}{|c|c|c|c|c|c|}
\hline \multirow{2}{*}{ Age group } & \multicolumn{5}{|c|}{ Duration of d/s } \\
\cline { 2 - 6 } & $\begin{array}{c}<\mathbf{1} \\
\text { month }\end{array}$ & $\begin{array}{c}\mathbf{1 - 6} \\
\text { months }\end{array}$ & $\begin{array}{c}\mathbf{6 - 1 2} \\
\text { months }\end{array}$ & $\begin{array}{c}\mathbf{1 - 5} \\
\text { years }\end{array}$ & $\begin{array}{c}>\mathbf{5} \\
\text { years }\end{array}$ \\
\hline 1-5 years & 4 & 2 & 1 & 0 & 0 \\
\hline 6-10 years & 5 & 5 & 8 & 4 & 0 \\
\hline 11-15 years & 7 & 4 & 0 & 5 & 2 \\
\hline$>15$ years & 3 & 4 & 2 & 2 & 4 \\
\hline Total & 19 & 15 & 11 & 11 & 2 \\
\hline
\end{tabular}

Chi Square Test $=24.797, \mathrm{df}=9 \mathrm{P}$ Value $=0.003$ Significant

having Grade 2 Impression Cytology show the highest percentage $48.1 \%$ for $1-6$ months duration while, the lowest percentage $1.9 \%$ had $>5$ years duration of disease at presentation. Patients having Grade 3 Impression Cytology showed a percentage of $24.1 \%$ for $1-6$ month and $>5$ years duration while, the lowest percentage $10.3 \%$ had 6-12 months duration of disease at presentation. Patients having Grade 4 Impression Cytology show 100\% for $>5$ years duration of disease at presentation.

The above table (Table 5) demonstrates the association between Impression Cytology and Clinical Forms of the respondents which found to be significant $(\mathrm{P}<0.05)$. It implies that Impression Cytology Grades of patients differ significantly with the Clinical Forms they had.

Patients having Grade 1 Impression Cytology show the highest percentage $68.2 \%$ for Palpebral while, the lowest percentage $4.5 \%$ had Mixed Clinical Forms. Patients having Grade 2 Impression Cytology show the highest percentage $46.4 \%$ for Limbal while, the lowest percentage $17.9 \%$ had Mixed Clinical Forms. Patients having Grade 3 Impression Cytology show the highest percentage $50 \%$ for Limbal while, the lowest percentage $10 \%$ had Mixed Clinical Forms.

The above table (Table 6) shows association between age and duration of disease at presentation of the respondents which found to be significant. It implies that the age group of the patients differ significantly with the duration of disease at which they presented.

Patients of the age group between 1-5 years showed the highest proportion for less than 1 month while none had between 1-5 years of duration of disease at presentation. Patients of the age group between 6-10 years showed the highest proportion between 6-12 months and none had more than 5 years of duration of disease at presentation. Patients of the age group between 11-15 years showed the highest proportion for more than 1 months while none had between 6-12 months of duration of disease. Patients of the age group above 15 years 
showed the highest proportion for 1-6 months of duration of disease while lower proportion above 6 months of duration of disease.

\section{DISCUSSION}

Our study showed that the clinical profile of $\mathrm{VKC}$ in central India is essentially similar to the pattern described in other countries. We had 60 patients of the age group ranging from 3 years to 23 years of age in which 41 were male and 19 were female with M:F ratio 2.1:1. Previous studies also showed similar results in which M:F Ratio was 3:1 (Saboo, 2013; Gokhale, 2016). Most of the cases (41.6\%) were found in age group of 11-15 years with mean age of presentation 11.1 years which was corresponding with other studies (Saboo, 2013; Gokhale, 2016). In our study we found patients from 3 years of age going up to 23 years of age which was against maximum age seen in other studies which was 12 years (Sacchetti et al, 2007). This may suggest a changing trend towards disease continuing in adults as well.

Changes in goblet cells morphology is studied by Impression Cytology and is classified according to Saini et al criteria and not by Nelson criteria because Saini et al takes into account multiple factors to determine the nature of conjunctival epithelial metaplasia like size and number of epithelial cells, shape of the nucleus, nucleocytoplasmic ratio and staining of goblet cells by Periodic acid- Schiff stain (PAS) while Nelson criteria only considers size of epithelial cells, shape of nucleus and number of goblet cells.
Maximally, mild disease based on Gokhle (2016), clinical grading was present in $46.66 \%$ patients and $15.83 \%$ of cases had severe form, other studies also observed similar results with $48.4 \%$ mild cases and severe forms found only in $9 \%$ of cases (Lambiase et al, 2009).

Most of our cases were mixed form (55\%) comprising both limbal as well as palpebral involvement followed by palpebral forms $(40 \%)$. Whereas another study observed that limbal forms $(53.8 \%)$ was the most frequent subtype of VKC (Lambiase et al, 2009). This difference in observation could have been because of varied climatic and geographical factors in the study area.

Central corneal opacity was seen in one case. Shield ulcer and chronic persistent inflammation leading to destruction of the limbal stem cells resulting in conjunctivalization of the cornea was not found in our series (Tabarra et al, 1999). Small sample size can be a reason for these observations.

On observing cytological changes, Grade 2 changes (as per Saini et al) were noticed in the majority of cases (45\%) followed by Grade 1 and 3 changes in $29.16 \%$ and $24.16 \%$ cases. Only $2(1.66 \%)$ cases had Grade 4 changes. Another study done on various groups of ocular surface disorders included 8 patients of VKC out of which six $(75 \%)$ cases showed grade 2 changes and $2(25 \%)$ cases had grade 3 changes on Impression Cytology (Thatte et al, 2016).

There is proportionate disturbance in ocular surface morphology with increasing severity 
of disease as $50 \%$ cases of milder forms had grade 1 changes, followed by grade 2 in $42.85 \%$ cases. In moderate forms grade 2 changes were more common $(56.81 \%)$ followed by grade $3(36.36 \%)$. Severe forms revealed mostly grade 3 changes in $42.10 \%$ cases. Grade 4 changes were seen in only 2 cases with severe form of disease. The only case with blinding form had grade 3 changes on Impression Cytology (Table 2). These results cannot be compared within groups as the number of cases were unequal in various groups. None of the previous studies conducted on Impression Cytology have specifically discussed VKC with comparing changes in different severity of disease.

In the age group of 0 to 5 years, grade 1 changes were common $(66.66 \%)$. Children of 6 to 10 years of age most commonly had grade 2 changes in $55.26 \%$ of cases. Amongst 11 to 15 years old kids also grade 2 changes were common, found in $44 \%$ of cases. In late teens $40 \%$ of cases had grade 3 changes. Thus, it is observed as age goes on increasing cytological changes on ocular surface were found to be more deranged and this we can correlate, that with increase in age and longer duration of the disease more deranged ocular surface changes were observed and it is the duration of the disease that correspond to ocular surface changes although this could not be statistically analysed due to varying sample size in different age groups.

Grading on Impression Cytology becomes severe as duration of disease increases. In cases with duration of disease less than 1 month,
Grade 1 changes were seen most commonly followed by grade 2 . Mostly Grade 2 was found in disease duration of 1 to 6 months, 6 to 12 months and 1 to 5 years. In patients with more than 5 years of disease history, Grade 3 changes were seen in $70 \%$ cases. Thus, it is observed that as the disease progresses and with increasing duration there is increase in the ocular surface damage.

\section{CONCLUSION}

VKC in India essentially follows a similar pattern seen in other countries, being more common in the second decade of life with a trend towards higher age and male predominance. Most of the patients present with mild intensity and mixed forms comprising both limbal as well as palpebral involvement. Grade 2 changes were seen on impression cytology in most of our cases. Changes in goblet cell morphology goes on increasing with growing age of patient,severity and duration of disease.

Palpebral form of VKC has mostly Grade 1 changes followed by Grade 2 changes while cases labelled as Limbal form has Grade 2 changes in majority of cases followed by Grade 1 changes. The cases which were labelled as Mixed form also showed Grade 2 changes in maximum cases followed by Grade 1 changes.

There is certainly need for further research on Ocular surface changes in VKC with a larger sample size so as to infer better results.

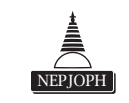




\section{REFERENCES}

Bonini S, Coassin M, Aronni S, Lambiase A (2004). Vernal keratoconjunctivitis. Eye;18(4):345-51. doi: 10.1038/ sj.eye. 6700675

Bowling B (2016). Vernal Keratoconjunctivitis ‘in’ Kanski’s Clinical Ophthalmology. Edinburgh (Elsevier):145-7.

Gokhale NS (2016). Systematic approach to managing vernal keratoconjunctivitis in clinical practice: Severity grading system and a treatment algorithm. Indian Journal of Ophthalmology;64(2):145. PMID: 27050351

Hagan S (2017). Biomarkers of ocular surface disease using impression cytology. Biomarkers in medicine;11(12):1135-47. doi: 10.2217/bmm-2017-0124

Lambiase A, Minchiotti S, Leonardi A, Secchi AG, Rolando M, Calabria G, et al (2009). Prospective, multicenter demographic and epidemiological study on vernal keratoconjunctivitis: A glimpse of ocular surface in Italian population. Ophthalmic Epidemiology;16(1):38-41. doi: 10.1080/09286580802573177

Leonardi A, Busca F, Motterle L, Cavarzeran F, Fregona IA, Plebani M, et al (2006). Case series of 406 vernal keratoconjunctivitis patients: a demographic and epidemiological study. Acta Ophthalmologica Scandinavica;84(3):406-10. doi: 10.1111/j.1600-0420.2005.00622.x

Pushpa V, Srivastava U, Singh S, Priti M, Sheetal P (2010). Conjunctival impression cytology a diagnostic boon in diagnosis of dry eye in presence of normal tear function test. AIOC proceedings.

Saboo US, Jain M, Reddy JC, Sangwan VS (2013). Demographic and clinical profile of vernal keratoconjunctivitis at a tertiary eye care center in India. Indian Journal of Ophthalmology;61(9):486. PMID: 24104706

Sacchetti M, Baiardini I, Lambiase A, Aronni S, Fassio O, Gramiccioni C, et al. (2007). Development and testing of the quality of life in children with vernal keratoconjunctivitis questionnaire. American Journal of Ophthalmology;144(4):557-63. doi: 10.1016/j.ajo.2007.06.028

Thatte S, Garg P (2016). Role of impression cytology in detecting goblet cell damage in various ocular surface disorder. Austin J Clin Ophthalmol;3:1065.

Singh R, Joseph A, Umapathy T, Tint NL, Dua HS (2005). Impression cytology of the ocular surface. British Journal of Ophthalmology;89(12):1655-9. doi: 10.1136/bjo.2005.073916

Singh S, Oli C, Mishra V, Singh D, Rana J (2017). Cytomorphology of conjunctival epithelium in ocular surface disorders. Int J Ophthalmic Pathol;6(1):2. doi: 10.4172/2324-8599.1000195

Tabbara KF (1999). Ocular complications of vernal keratoconjunctivitis. Canadian Journal of Ophthalmology (Journal canadien d'ophtalmologie);34(2):88-92. PMID: 10321319

Ukponmwan CU (2003). Vernal keratoconjunctivitis in Nigerians: 109 consecutive cases. Tropical doctor;33(4):242-5. doi: $10.1177 / 004947550303300419$ 